$\underline{\xi}=$

\title{
Potential use of bacteriocin producing lactic acid bacterial strain isolated from milk products and its application as the fish feed
}

\author{
Khumbongmayum Sumita Devi ${ }^{1 *}$, Veena Gayathri Krishnaswamy ${ }^{1}$ \\ ${ }^{1}$ Department of Biotechnology Stella Maris College, Chennai-87, Tamilnadu, India \\ *Corresponding authorE-mail:veenagayathri@yahoo.com
}

\begin{abstract}
Bacteriocins are gene-encoded inhibitory proteins and those produced by Gram-positive Lactic acid bacteria. Some bacteriocins even display antagonistic activity towards Gram-positive food borne pathogens and spoilage organisms. This present study involves isolation of Bacteriocin-producing lactic acid bacteria from a variety of milk and milk products. The physico-chemical properties of the isolated bacteriocin producing bacterial strains were screened. The isolated bacteriocin bacterial strains were biochemically characterized and identified. Further, the isolated effective bacterial strain was used as a fish feed and its effect on their growth was evaluated. The evaluated data continue to demonstrate that the bacteriocin producing bacterial strains will have greater potential in the food products industry.
\end{abstract}

Keywords: Bacteriocin; Lactic acid Bacteria; Pathogens; Antagonism; Antimicrobial property.

\section{Introduction}

Probiotics are live, non-pathogenic microorganisms, which when ingested reaches the gut to confer positive health benefits to the host as reported by De Vrese and Schrezenmeir [1]. The importance of colonic bacteria and the need to study probiotics has gained great attention in the last few decades in accordance with Brooks and Kalmokoff [2]. Vouloumanou et al. [3] reported beneficial effects of such Probiotics include prevention and reduced severity of respiratory infections as solved by, diminished and manageable symptoms of irritable bowel disease of the lower gastrointestinal tract as reported by Hungin et al.[4] and curing acute infectious diarrhoea [5].

Lactic acid bacteria produce a variety of substances with antimicrobial activity, including antimicrobial peptides collectively known as bacteriocin[6]. Bacteriocins are known for their low toxicity, high potency in situ production as reported by Cotter et al. [7] and for their greater specificity of in their antoagonistic activities aiding the producer in accordance to the study of Sahoo et al. [8]. Frequent use of antibiotics has led to the emergence of antibiotic resistance in bacteria. Lantibiotics are lanthioninecontaining antibiotic peptides as studied by Sahl and Bierbaum [9]. Lantibiotic compounds are ribosomally synthesized antimicrobial peptides against which bacteria are not able to produce resistance, hence making them a good alternative to antibiotics according to the findings of Singh and Sareen [10]. Hence the present study was used for isolation of bacteriocin producing Lactic Acid Bacteria from milk and milk products. The physicochemical properties of the bacteriocin producing bacterial strains were screened. Further, the effective isolated bacterial strain was prepared as a fish feed and its effect to enhance the growth of the fish was evaluated.

\section{Materials and methods}

\subsection{Samples and enrichment of the bacterial strains}

The samples were collected from both natural sources (milk, curd, etc) and artificial sources (Yoghurt, cheese and butter samples). Serial tenfold dilutions of the samples were made with sterile distilled water, of which $0.1 \mathrm{ml}$ of the sample was plated on to sterile de-Mann, Rogosa and Sharpe (MRS) agar from $10^{-5}$ to $10^{-7}$ dilutions. The medium used was autoclaved at $121^{\circ} \mathrm{C}, 15$ psi pressure. The milk samples were serially diluted in peptonated saline solution and plated out onto MRS (deMan Rogasa Sharpe) agar plates, supplemented with $50 \mathrm{mg} /$ litre Natamycin to avoid yeast contamination. The plates were incubated at $37^{\circ} \mathrm{C}$ for 48 hours. The pure colonies were maintained in the same agar as slants and supplemented with $15 \%$ glycerol.

\subsection{Standard indicator bacterial strains}

The following are the indicator organisms used for study were purchased from NCIM.

Bacillus cereus (NCIM 2106), Staphylococcus aureus (NCIM 2127), Escherichia coli (NCIM 2068), Proteus mirabilis (80CC 29906) and Klebsiella pneumoniae (NCIM 2883).

\subsection{Antagonistic activity}

Cultures incubated for $37^{\circ} \mathrm{C}$ at $24 \mathrm{hr}$ were swabbed on the MRS agar plates. Wells were created in the MRS agar plates and $50 \mu 1$ of test pathogenic organisms (Escherichia coli, Staphylococcus aureus, Bacillus cereus, Klebsiella pneumoniae and Proteus mirabilis) were added into the wells and incubated at $37^{\circ} \mathrm{C}$ for $24 \mathrm{hrs}$. 


\subsection{Production and purification of bacteriocin}

Isolated Bacterial strains were propagated in $100 \mathrm{ml}$ MRS broth for 72 hours at $37^{\circ} \mathrm{C}$. For extraction of bacteriocin, a cell free solution was obtained by centrifuging the culture at $10,000 \mathrm{rpm}$ for 20 minutes at $4^{\circ} \mathrm{C}$. It was adjusted to $\mathrm{pH} 7.0$ by means of $1 \mathrm{M} \mathrm{NaOH}$ to rule out the antimicrobial effect of organic acid, followed by filtration of the supernatant. Ammonium sulphate competes with the protein present in the solution against the water gradient and gradually, precipitates the protein. The crude bacteriocin was treated with different concentration of ammonium sulphate; $10,20,30,40,50,60,70$ and $80 \%$ respectively. After $3 \mathrm{hrs}$, the suspension was centrifuged at $10,000 \mathrm{rpm}$ for $30 \mathrm{mins}$. The supernatant from each concentration was dialyzed against deionized water with four changes over 3 days and tested for antimicrobial activity with the method of Elizete et al. [11].

\subsection{Agar well diffusion method}

Pre-poured brain heart infusion (BHI) agar plates were overlaid with $3.0 \mathrm{ml}$ BHI soft agar containing $0.1 \mathrm{ml}\left(28 \times 10^{6}\right)$ sensitive culture. Wells (5mm in diameter) were cut into these agar plates and $50 \mu \mathrm{l}$ of the culture supernatants was placed into each well, and kept at $4^{0} \mathrm{C}$ for 10 to $12 \mathrm{~h}$ to allow the bacteriocins to diffuse into the agar. The plates were then incubated at $37^{\circ} \mathrm{C}$ for $24 \mathrm{~h}$ and zone of inhibition were measured in $\mathrm{mm}$ diameter. Preparation of cell free neutralized supernatant (CFNS): producer strain was grown overnight at $37{ }^{0} \mathrm{C}$. Supernatant fluid was obtained by centrifuging at $10,000 \mathrm{~g}$ for min. $\mathrm{pH}$ of the supernatant was adjusted to 7.0 with $1 \mathrm{NaOH}$ (Merck, Darmstadt, Germany) (filter sterilized through a filter membrane of $0.22 \mu \mathrm{m}$ (Millipore corp., Bedford, Mass)). Cell free neutralized supernatant (CFNS) is widely used for final characterization of bacteriocin or bacteriocin-like inhibitory substances from indigenous lactic acid bacteria.

\subsection{Physical characterization of bacteriocin}

\section{6.1. Effect of $\mathrm{pH}$ and temperature}

Bacteriocin preparations were adjusted to different $\mathrm{pH}$ levels between 1.0 to 10 with $1 \mathrm{~N} \mathrm{NaOH}$ or $10 \mathrm{mM} \mathrm{HCl} \mathrm{(pH-meter:} \mathrm{EDT}$ Instruments, UK). Samples were maintained for $1 \mathrm{~h}$ at $37^{\circ} \mathrm{C}$. All the samples were then re-adjusted to neutral $\mathrm{pH}(\mathrm{pH} 7.0)$ and assayed for activity by agar well diffusion assay using the method of Bhunia et al. [12].

The thermo stability of the bacteriocin preparations were determined by heating $2.0 \mathrm{ml}$ of the preparations at $40^{\circ} \mathrm{C}, 60^{\circ} \mathrm{C}, 80^{\circ} \mathrm{C}$ and $100^{\circ} \mathrm{C}$ for $30 \mathrm{~min}$. Samples were removed at intervals of 5 minutes, cooled and assayed for remaining activity as done by Rasool et al. [13].

\subsection{Chemical characterization of bacteriocin}

\subsubsection{Effect of $\mathrm{NaCl}$ on the production of bacteriocin}

A set of fresh tryptone soya broth (TSB: tryptone1.5\%, soya peptone $1.0 \%$ ) containing $\mathrm{NaCl}$ at a final concentrations of $0.5,1.0$, 2.5 and $5 \%$ was inoculated with a fixed volume of inoculums of $\mathrm{KS} 1$ culture. Broth without $\mathrm{NaCl}$ solution was taken as control The optical density and bacteriocins activity was determined after day $0,1,2,3$ and 4 as solved by Bhunia et al. [12]

\subsubsection{Effect of organic solvents on the production of bacterioc- in}

Equal volumes of CFNS were mixed with different organic solvents like methanol, ethanol, formaldehyde, chloroform and isopropanol in the final concentration of $1.0 \%$ (pre-cooled at $4^{0} \mathrm{C}$ ). All the organic solvents were obtained from Sigma except chloroform which was obtained from BDH. Samples were stirred and incubated at $37^{\circ} \mathrm{C}$ for $30 \mathrm{~min}$ and evaporated in a rotary evapora- tor (Rotavapor, Buchi-461, Sibata, Switzarland). Dried samples were dissolved in $50 \mathrm{mM}$ sodium phosphate buffer, $\mathrm{pH} 7.0$ and assayed for antimicrobial activity using the method of Bhunia et al. [12].

\subsubsection{Effect of surfactants and bile salt concentration}

Bacteriocin preparations were treated with different detergents: triton X-100, sodium dodecyl sulphate (SDS), ethylene diamine tetra acetic acid (EDTA), tween 20 and tween 80 at a final concentration of $1.0 \%$. Control consists of either bacteriocin preparation or detergent in $50 \mathrm{mM}$ sodium phosphate buffer, $\mathrm{pH} 7.0$. All the samples and controls were incubated at $37^{\circ} \mathrm{C}$ for $6 \mathrm{~h}$ and titers for bacteriocins activity were determined as done by Muriana and Klaenhammer [14].The zone of inhibition was measured in BHI agar plate and $\mathrm{AU} / \mathrm{mL}$ was noted. The effect of bile salt concentration was determined in various bile salt concentrations $(0.5 \%$ to $2 \%)$.

\subsection{Critical dilution assay}

A series of two-fold dilutions of crude bacteriocin preparation was made in the same medium (MRS broth) used for the growth of producer as well as indicator strain as done by Hardy [15]. Antagonistic activity of each dilution was assayed by dropping $10 \mu \mathrm{l}$ of each dilution onto the MRS agar plate pre-incubated with Bacillus cereus (as sensitive culture). The plates were incubated at $37^{\circ} \mathrm{C}$ for 18-24 $\mathrm{h}$ and zone of inhibition were measured in $\mathrm{mm}$. The bacteriocin titre (inhibitory activity) was expressed as arbitrary units $/ \mathrm{ml}$. Arbitrary units (AU) is defined as $10 \mu 1$ of the highest dilution of crude preparation yielding a defined zone of inhibition on the lawn of cells of Bacillus cereus as solved by Pucci et al. [16], as was calculated as : reciprocal of the highest dilution giving definite zone of inhibition divided by the volume of CFNS dropped on the pre-poured sensitive culture plate $(10 \mu 1)$ multiplied by 1000 for ml calculations according to the method of Bhunia et al. [17].

\subsection{Minimal inhibitory concentration (MIC)}

\subsubsection{Tube dilution test}

Two-fold dilutions of bacterial preparation culture isolates were prepared in $50 \mathrm{mM}$ sodium phosphate buffer $(\mathrm{pH} 7.0)$. A standard inoculum $\left(2 \times 10^{8}\right.$ cell) of the test organism (Bacillus cereus) was added and was incubated at $37^{\circ} \mathrm{C}$ for $18 \mathrm{~h}$. The lowest dilution of the bacteriocin preparation that prevents visible growth of sensitive culture was noted as the minimal inhibitory concentration (MIC).

\subsection{Detection of the bacteriocin activity}

Bacteriocin activity of the cell free- supernatant of KS1 was checked by spot-on-the lawn method. Activity was measured as the reciprocal of the highest two-fold dilution showing antimicrobial activity. According to the study, 1/8 was the highest dilution showing antimicrobial activity against the indicator strain Bacillus cereus which was used in all measurements for bacteriocins activity.

Bacteriocin activity of cell-free supernatant of KS1 (crude extract) was calculated as:

$$
\begin{aligned}
& 8 \times 200=1600 \mathrm{AU} / \mathrm{ml} \\
& \mathrm{AU} / \mathrm{ml}=\text { Arbitrary Unit; }
\end{aligned}
$$

$8=$ reciprocal of the highest dilution $(1 / 4 ;) 200=1000 \mu \mathrm{l} / 5 \mu \mathrm{l}$ (conversion factor)

An example to the titration of the bacteriocin activity of the fraction obtained by ammonium sulphate precipitation of the supernatant of KS1, the highest dilution which showed a clear zone on the 
lawn was $1 / 8$. According to the above formula, the corresponding bacteriocin activity was calculated as $8 \times 200=1600 \mathrm{AU} / \mathrm{ml}$.

\subsection{Morphological identification of the isolated} bacterial strains

The isolated LAB were first set to Gram's staining and motility test after which biochemical characterization such as the test for Catalase, Urease, IMViC, Indole production were investigated along with Methyl Red-Voges Proskauer (MRVP) Test, Citrate utilization test, Triple Sugar -Iron Agar Test. In order to test the antibiotic resistance $24 \mathrm{~h}$ old MRS broth culture (taken from single colonies on MRS agar) was swabbed on Mueller Hinton agar and incubated at $37^{\circ} \mathrm{C}$ for $24 \mathrm{~h}$. Resistance was assessed against gentamicin, trimoxazole, azithromycin, tetracycline and amoxicillin. Basal Nutrient agar supplemented with Sheep Blood (collected from the jugular vein in sterile $3.80 \%$ Trisodium citrate $(1 \mathrm{~mL}$ citrate solution for $10 \mathrm{~mL}$ blood))was used to test the haemolytic activity of the isolated bacteria. $10 \mathrm{~mL}$ of the blood was aseptically added to $90 \mathrm{~mL}$ of the base. It is mixed well and poured in the plate.

\subsection{Influence of bacteriocin produced by KS1 on the fish feed}

Commercial fish feed and puffed rice were coated with bacterial isolate and two fish (1 and 2) were fed separately in different container. Fish 1 was fed with uncoated commercial fish food and served as control. Fish 2 was fed with bacteriocin coated fish feed served as test.

\subsubsection{Procedure of coating bacterial strain to fish foods}

Bacterial isolates were grown in MRS broth in a shaking incubator at $37^{0} \mathrm{C}$ overnight. After incubation, the cells were harvested by centrifugation (2000 rpm), washed twice with PBS buffer and resuspended in the same buffer. The absorbance at $600 \mathrm{~nm}$ was adjusted to standardize the number of bacteriocin $\left(10^{5}-10^{6}\right.$ $\mathrm{CFU} / \mathrm{mL}$ ). Probiotic diets were prepared with cells resuspended in $5 \mathrm{~mL}$ of PBS to $10^{6} \mathrm{CFU}$ and mixed.

Fishes were fed twice everyday with the parameters of $5 \%$ body weight per day with $80 \%$ water change every day, during 15 days feeding trials and survival was estimated visually each morning and body weights were measured in every 5 days as done by Vijayabaskar and Somasundaram [18].

\section{Results}

Milk samples were used from both natural and artificial sources, out of which, four strains named KS1, KS2, KS3, KS4 isolated from artificial sources were able to produce bacteriocin. When the isolated four strains where compared for bacteriocin production KS1 was able to shown effective bacteriocin production. $\mathrm{pH}$ experiment results showed that there were no activity at $\mathrm{pH} 1$ and 2 , and bacteriocin activity increased from $\mathrm{pH} 3$ to 5 . The bacteriocin produced by the KS1 was stable till $10 \mathrm{~min}$ in every temperature used, but was labile at $100^{\circ} \mathrm{C}$ after $30 \mathrm{~min}$. The maximum activity of bacteriocin was found at $80^{\circ} \mathrm{C}$. Effect of $\mathrm{NaCl}$ played an important role on the bacteriocin activity, hence in this study the $\mathrm{NaCl}$ concentrations were studied from $0.5 \%$ to $25 \%$. It was noted that zone of inhibition $(20 \mathrm{~mm})$ was maximum in $2.5 \%$ of $\mathrm{NaCl}$ concentration on $2^{\text {nd }}$ day. $\mathrm{NaCl}$ concentration of $0.5 \%$ and $1 \%$ reached its maximum zone $(6 \mathrm{~mm})$ of inhibition in $1^{\text {st }}$ and $2^{\text {nd }}$ day. $5 \% \mathrm{NaCl}$ concentration reached maximum zone $(6 \mathrm{~mm})$ of inhibition in $1^{\text {st }}$ day. In control, maximum zone $(10 \mathrm{~mm})$ was shown in $1^{\text {st }}$ day. The maximum activity of bacteriocin was achieved of about $160 \mathrm{AU} / \mathrm{mL}$ with $2.5 \% \mathrm{NaCl}$. This was co-related with growth of KS1. To study the effect of organic solvents on CFNS of $\mathrm{KS} 1$ isolate by using $\mathrm{B}$. cereus as indicator strain, different organic solvents were treated with CFNS. Formaldehyde and Chloroform showed zone of inhibition of $10 \mathrm{~mm}$ whereas Methanol showed $6 \mathrm{~mm}$. In formaldehyde bacteriocin activity was about
$80 \mathrm{AU} / \mathrm{mL}$, whereas with Chloroform and Methanol as the organic solvents, bacteriocins showed maximum activity of about 160 AU/mL. Chloroform showed maximum zone $(10 \mathrm{~mm})$ of inhibition and arbitory unit (160 AU/mL) .Effect of surfactants on bacteriocin showed a varied activity. Tween 20 and SDS showed less zone of inhibition $(10 \mathrm{~mm})$ whereas EDTA had greater zone (26 $\mathrm{mm})$. But all the surfactants showed the maximum activity up to $160 \mathrm{AU} / \mathrm{mL}$. This proved that bacteriocin produced by the bacterial strain KS1 showed maximum activity with all the surfactants used in the study.

The KS1 isolate can survive in the presence of bile salt, but growth decreases with the increase of bile salt concentration. In MRS agar plate, production of bacteriocin studied by agar well diffusion method showed KS1 inhibits Escherichia coli $(34 \mathrm{~mm})$ more strongly than Bacillus cereus $(8 \mathrm{~mm})$. There was no inhibition against Staphylococcus aureus, Proteus mirabilis and Klebsiella pneumoniae.

Antimicrobial activity of cell free neutralized supernatant of all bacteriocin producing strains were checked against Bacillus cereus, Staphylococcus aureus, Escherichia coli, Proteus mirabilis and Klebsiella pneumoniae. The result showed that there is no inhibition against Staphylococcus aureus, Proteus mirabilis and Klebsiella pneumoniae while the antimicrobial activity was against Escherichia coli and Bacillus cereus. Maximum inhibition was shown against Bacillus cereus by CFNS of KS1, KS2, KS3 and KS4. KS1 showed the highest zone of inhibition $(40 \mathrm{~mm})$ followed by KS2 $(20 \mathrm{~mm}), \mathrm{KS} 3(18 \mathrm{~mm})$ and KS4 (18 mm). Minimum inhibitory concentration of bacteriocin produced by KS1 showed up to $1 / 8$ dilution of the bacteriocin against Bacillus cereus.

\subsection{Identification of the bacterial strains}

Table 6 summarizes the results of the biochemical tests of the isolated bacterial strains. The isolated strains KS1, KS2, KS3 and KS4 were rod like and showed small round white colonies. Morphological test shows that all the isolated bacterial strains were gram positive. By comparing Bergey's manual of Determinative Bacteriology it was found that all the isolates were Lactobacillus $\mathrm{sp}$. as the TSI agar results showed only acid production for all the isolates.

\subsection{Influence of bacteriocin produced on fish feed}

It was noted that both fish 1 and 2 had increased in weight $(5.2 \mathrm{~g}$ to $5.71 \mathrm{~g}$ and $5.3 \mathrm{~g}$ to $5.83 \mathrm{~g}$ ). When compared to commercial and natural (puffed rice) fish feed, it was observed that fish 2 fed with bacteriocin produced by KS1 exhibited greater increase in weight while fish 1 fed with commercial food showed slight increase in weight. From this result, it is predicted that the bacterial isolate which could be non-toxic, could prevent fish pathogen by producing potential bacteriocin and other antimicrobial substances.

\section{Discussion}

Bacteriocins are bactericidal or bacteriostatic peptides that are mostly active against closely related to the producer. Among the lactic acid bacteria (LAB) a high diversity of bacteriocins are produced of which several have been patented for applications in food. They have considerable attention as food preservatives and as potential replacement of antibiotics according to the finding of Veera et al. [19].

Sumathi and Reetha [20] isolated probiotic strains of Lactobacillus spp. which were isolated from different commercially prepared milk products such as milk, curd, yogurt, cheese and butter. The spectrum of inhibitory activity of the bacteriocin producers against Gram positive and Gram negative pathogens were tested and observed that activity was restricted to Gram positive organisms, but Lactobacillus and Streptococcus were active against both Gram positive and Gram negative organisms. 22 isolates were observed 
as the positive for bacteriocin production against food pathogen $L$. monocytogenes.

The present study was carried out to isolate bacteriocin producing bacterial strains from milk products such as milk, curd, butter, cheese and yogurt. The inhibitory activity of the isolated bacterial strains was checked against gram positive and gram negative pathogenic bacteria. Only four bacterial strains were able to produce "bacteriocin" KS1, KS2, KS3 and KS4 which were isolated from butter, cheese and yogurt and were observed as positive for Bacillus cereus and Escherichia coli. KS1 bacterial strain showed higher production of bacteriocin and as well as antibacterial activity $(40 \mathrm{~mm})$ against the pathogens.

Natthida et al. [21] checked for thermostability of bacteriocin producing bacterial isolates isolated from pickled Garcinia schomburgkiana Pierre. The crude bacteriocin was thermostable since its activity was still found at $60^{\circ} \mathrm{c}$ to $100^{\circ} \mathrm{C}$ and $60^{\circ} \mathrm{C}$ to $90^{\circ} \mathrm{C}$ for 15 and $30 \mathrm{~min}$, respectively, while any activity did not appear at $100^{\circ} \mathrm{C}$ for $30 \mathrm{~min}$. Thus, the crude bacteriocin was stable on heat treatment up to $80^{\circ} \mathrm{C}$ for $15 \mathrm{~min}$.

In the present study, bacteriocin produced by KS1 was effective in a wide range of temperature for $10 \mathrm{~min}$ and activity was maximum upto $160 \mathrm{AU} / \mathrm{mL}$ at $80^{\circ} \mathrm{C}$. There was no activity found by the bacteriocin produced by KS1 when the temperature was increased to $100^{\circ} \mathrm{C}$ for $30 \mathrm{~min}$. This results correlates with the results of the above mentioned author.

Veera et al. [19] studied lactic acid bacteria isolated from curd samples and they checked for tolerance to bile salt and $\mathrm{NaCl}$ concentration. Both the two isolates were tolerated to bile salt. Among the two strains, one strain showed comparatively better tolerance at $1 \%$ and $2 \%$ concentrations for $8 \mathrm{~h}$. The $\mathrm{NaCl}$ effect on growth of both the strains in the medium was studied. Both the organisms $(0.815$ and 0.926$)$ were tolerated at $1 \% \mathrm{NaCl}$ and lowered the growth $(0.083$ and 0.085$)$ at $5 \%$. In the present study KS1 tolerated to bile salt concentrations from $0.5 \%$ to $2 \%$ till $48 \mathrm{~h}$ of incubation. Bacteriocin activity was studied from $0.5 \%$ to $5 \% \mathrm{NaCl}$ concentration and growth of $2.5 \%$ and $5 \%$ were noted to 1.692 and 0.825 respectively.

Aguilar et al. [22] showed antimicrobial bacteriocin produced in supplemented MRS broth showed a broad antimicrobial spectrum determined by well diffusion assay against all strains of Listeria monocytogenes and Lactobacillus sakei ATCC 53103, Enterococcus faecium CHUM, L. delbrueckii subsp.lactis ATCC 12315, L. acidophilus ATCC 43121. Inhibition zones obtained in this trial measured $2 \mathrm{~mm}$ to $5 \mathrm{~mm}$. The present study showed the antibacterial activity produced by bacteriocin producing Lactobacillus sp. against Bacillus cereus by agar well diffusion method, it was upto a maximum zone of inhibition of $40 \mathrm{~mm}$ which was maximum compared to other literatures.
Musikasang et al. [23] checked antibiotic sensitivity of their isolated LABs against various antibiotics. To penicillin $\mathrm{G}$, all LAB strains showed high susceptibility to erythromycin (MIC $<0.25$ $\mu \mathrm{g} / \mathrm{ml}$ ) and tetracycline. All selected LAB strains showed a moderate resistance to chloramphenicol (MBC $8 \mu \mathrm{g} / \mathrm{ml}$ ) and most of them exhibited high MBC values (64-128 $\mu \mathrm{g} / \mathrm{ml})$. In the current study, bacteriocin produced by KS1 was checked for antibiotic sensitivity. It was sensitive to Gentamicin, Co-trimoxazole, Azithromycin, Tetracycline, and resistant to Amoxicillin (6 mm). Lacticacid bacteria contributes to the taste and texture of fermented products and inhibits food spoilage bacteria by producing growth-inhibiting substances and large amounts of lactic acid. As agents of fermentation, Lacticacid bacteria are involved in making yogurt, cheese, cultured butter, sour cream, sausage, cucumber pickles, olives and sauerkraut. Lactobacillus and Bifidobacterium spp. are prominent members of the commensal intestinal flora and are the commonly studied probiotics bacteria as shown by Mahsa et al. [24].

In the present study, Lactobacillus sp. (KS1) which was producing bacteriocin was very effective in using it for both commercial fish feed and natural fish feed increase in the weight of the fishes proved that such a bacterial strain was found to be non-toxic and could prevent other pathogenic bacteria affecting the fish growth. Hence isolation of such bacteriocin producing LAB could be of great use in food industry which especially helps in food industry in feed. Barbour et al. [24] studied the variable Characteristics of Bacteriocin-Producing Streptococcus salivarius strains (Lactic acid bacteria) isolated from Malaysian Subjects.

\section{Conclusion}

Bacteriocins are produced mostly a by lactic acid bacterium which play a major role as a probiotics and confers a great health benefits for host. In the present study we isolated bacteriocin producing bacterial strains (KS1, KS2, KS3 and KS4) from butter, cheese and yogurt studied their antimicrobial activity against human pathogenic organisms which caused gastrointestinal tract infections, including Bacillus cereus and Escherichia coli (opportunistic human pathogens). Heat, $\mathrm{pH}$ and bile salt stability of bacteriocin produced by KS1 strain shows its capability to survive in gastro intestinal tract of animals which can inhibit other opportunistic bacteria in the gastrointestinal tract. The research work also revealed non-toxic nature of the bacterial isolate which can be used as probiotic food to increase the height and weight of the fish. The antagonistic activity of the isolated bacterial strain could keep the health of the fish and protected them from pathogenic strains. This could be of great use to increase the breeding of fishes and helps to maintain the quality of the fishes in the fish industry.

\section{Acknowledgement}

We express my sincere thanks to Department of Biotechnology and Management of Stella Maris College for providing all the facilities for successful completion of the project. 


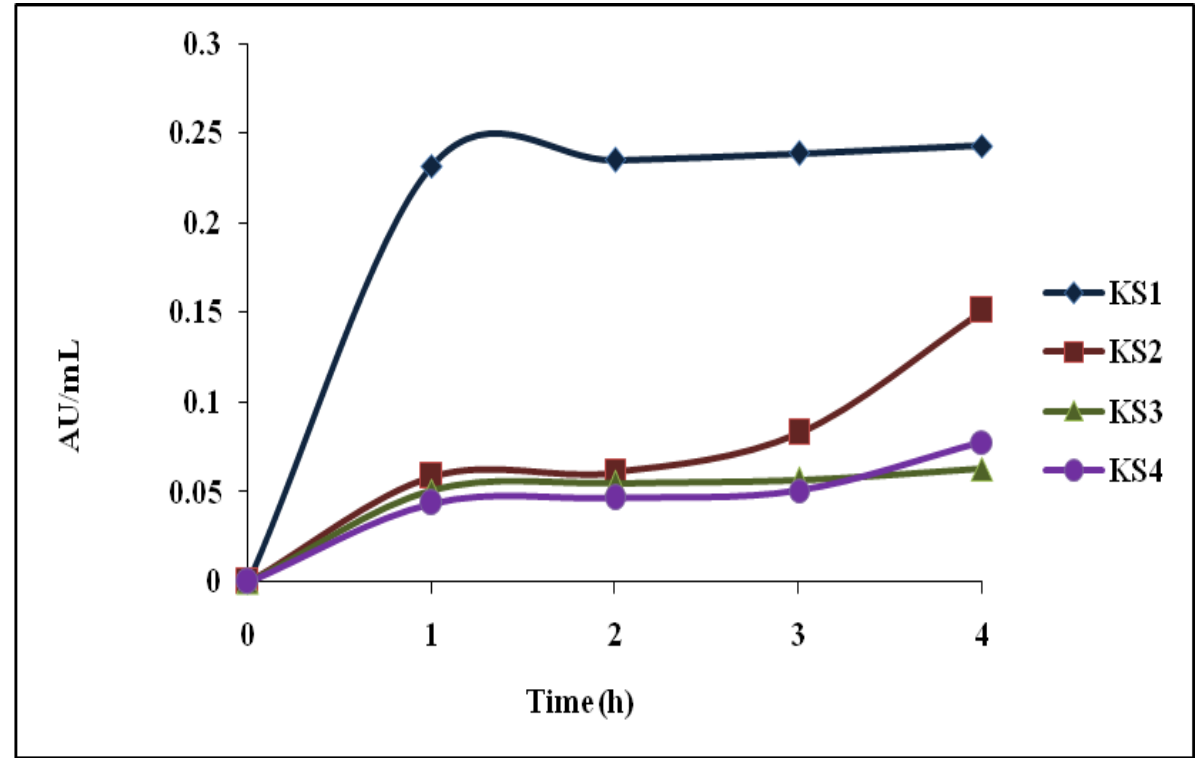

Fig. 1: Growth Pattern and Bacteriocin Production by the Isolated Bacterial Strains.

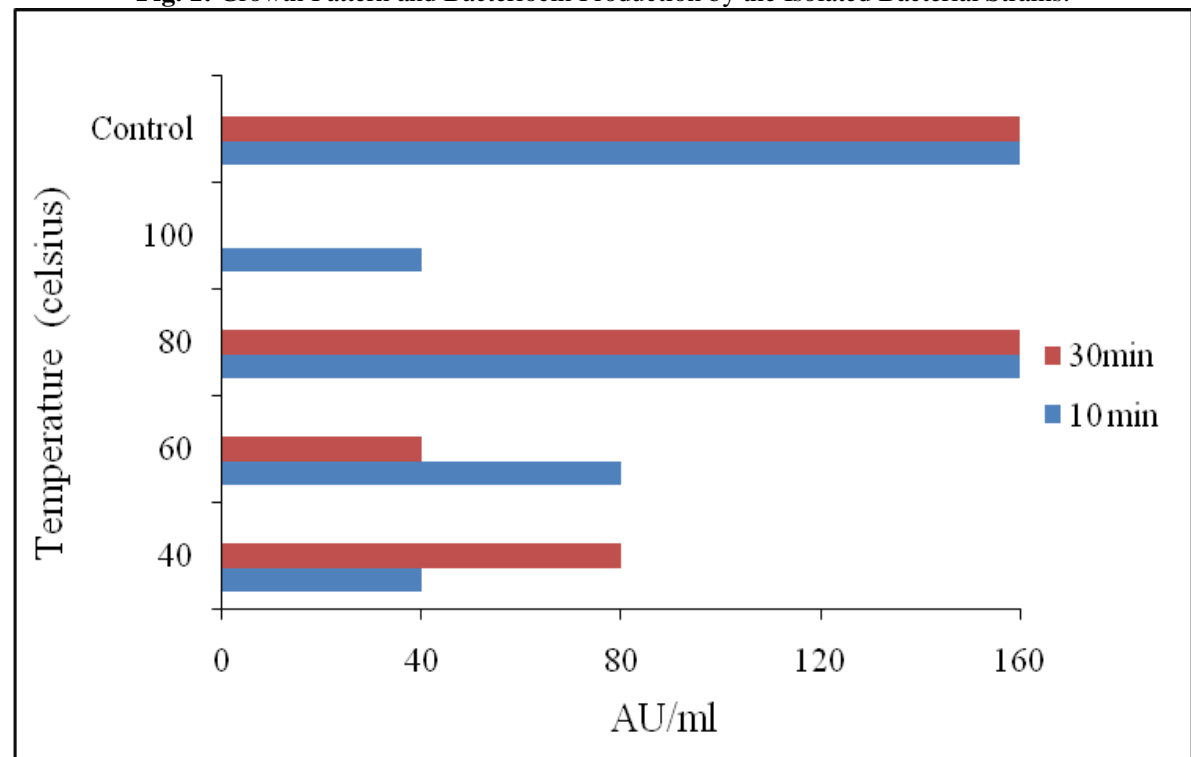

Fig. 2: Effect of Temperature on Bacteriocin production by KS1 Strain.

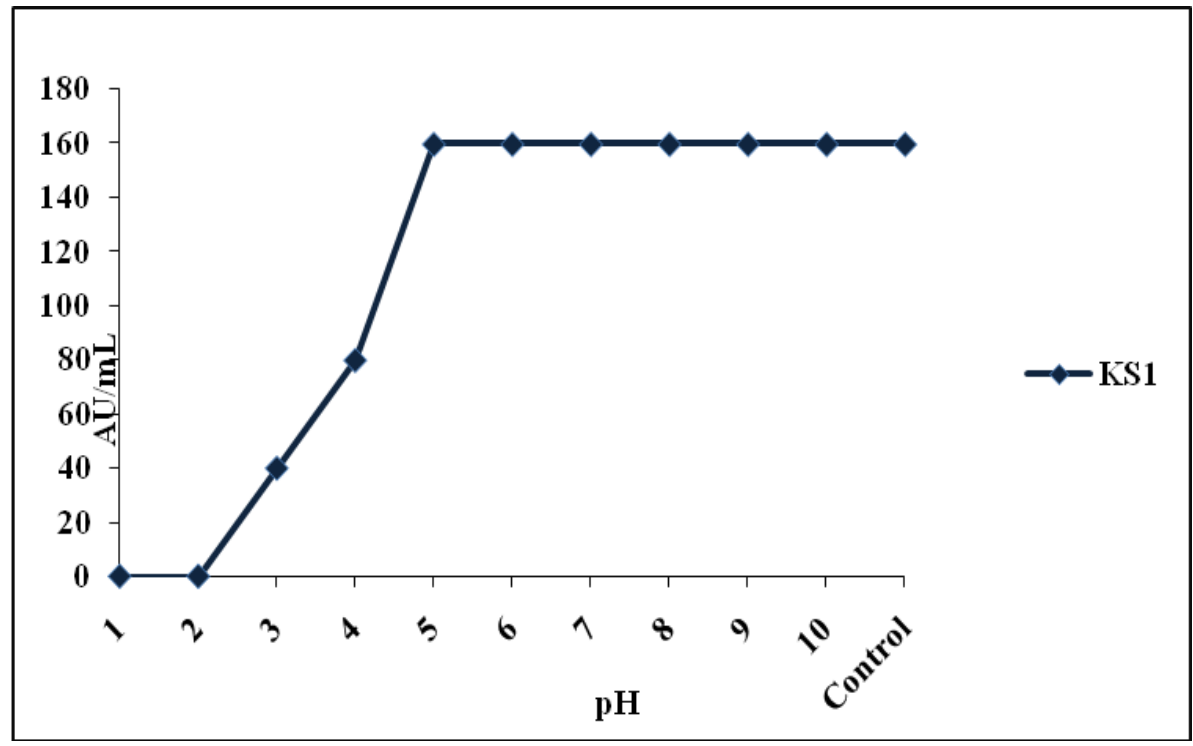

Fig. 3: Effect of $\mathrm{pH}$ on Bacteriocin Production by KS1 Strain 


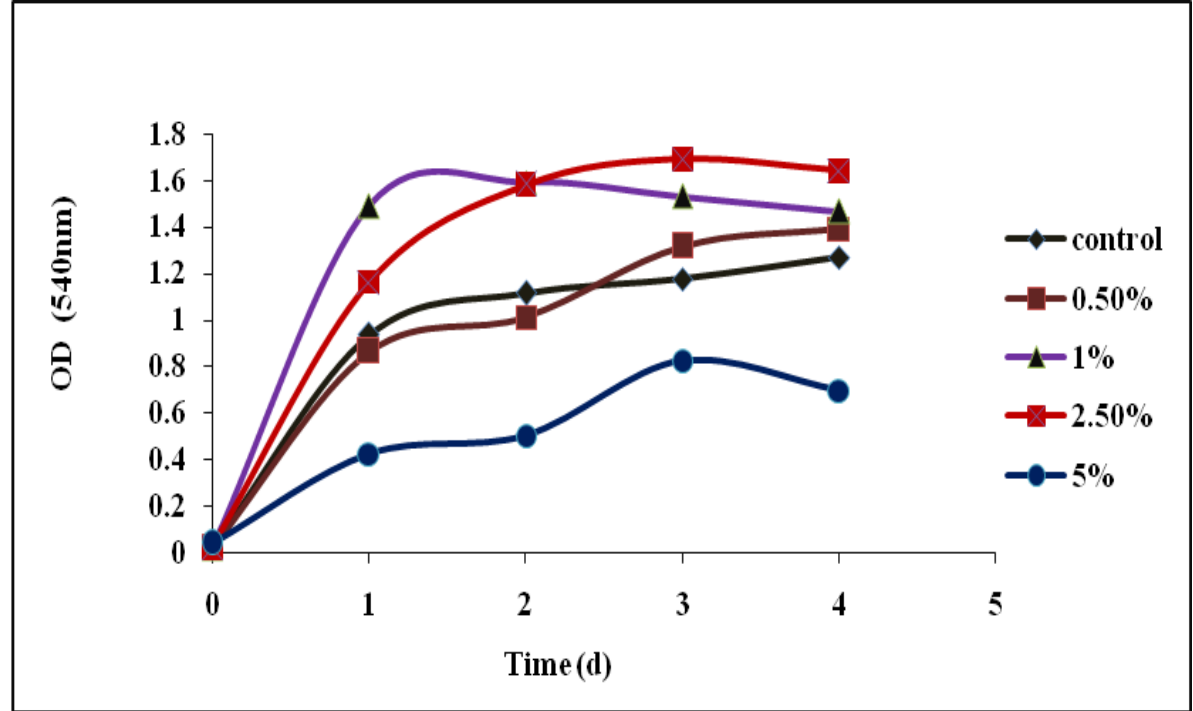

Fig. 4: Effect of $\mathrm{NaCl}$ Concentrations on Growth of KS1 Strain

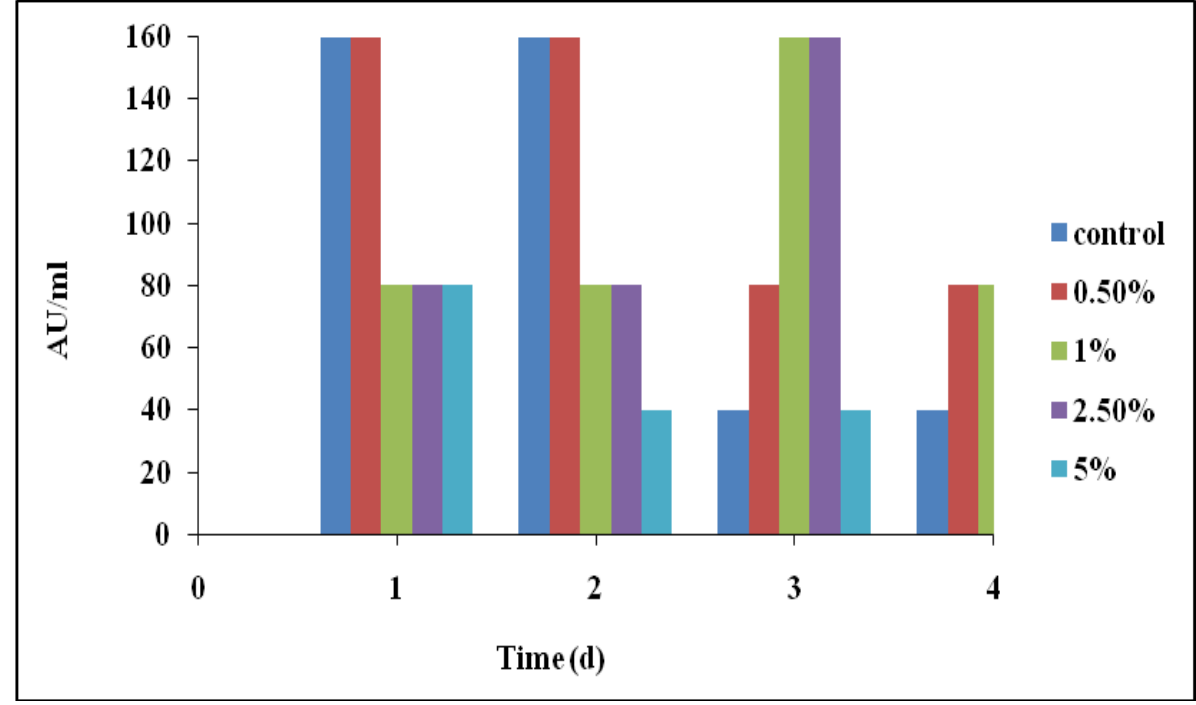

Fig. 5: Effect of $\mathrm{NaCl}$ Concentrations on Bacteriocin Production by KS1 Strain.

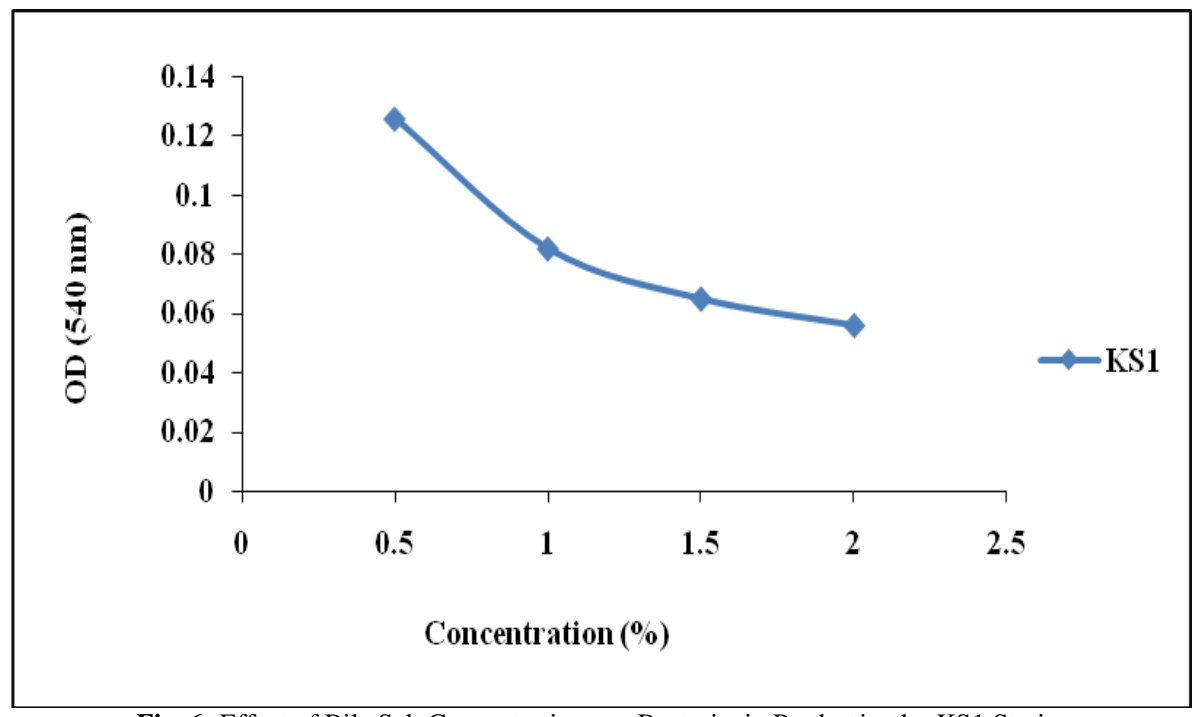

Fig. 6: Effect of Bile Salt Concentrations on Bacteriocin Production by KS1 Strain. 


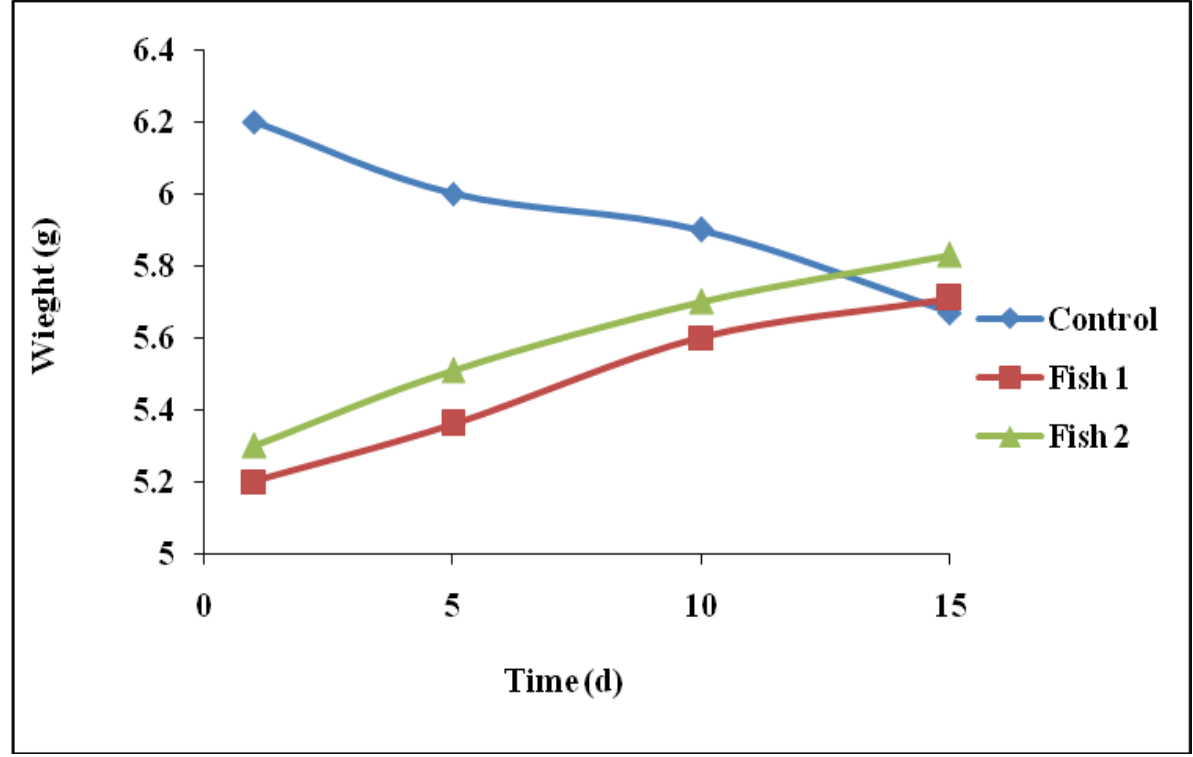

Fig. 7: Influence of Bacteriocin on Fish Feed (Fish 1-Commercial Food and Fish 2- Puffed Rice.

Table 1: Effect of Temperature on Bacteriocin Production by KS1 Strain

\begin{tabular}{lll}
\hline Temperature $\left({ }^{\circ} \mathrm{C}\right)$ & Activity in AU/mL & 30 min \\
\hline 40 & $10 \mathrm{~min}$ & 80 \\
60 & 40 & 40 \\
80 & 80 & 160 \\
100 & 160 & 0 \\
Control & 80 & \\
\hline
\end{tabular}

Table 2: Effect of $\mathrm{pH}$ on Bacteriocin Activity in AU/M

\begin{tabular}{lll}
\hline $\mathrm{pH}$ & Zone of inhibition in diameter $(\mathrm{mm})$ & Activity in AU/mL \\
\hline 1 & 0 & 0 \\
2 & 0 & 0 \\
3 & 10 & 40 \\
4 & 4 & 80 \\
5 & 36 & 160 \\
6 & 4 & 160 \\
7 & 28 & 160 \\
8 & 2 & 160 \\
9 & 8 & 160 \\
10 & 20 & 160 \\
Control & 40 & 160 \\
\hline
\end{tabular}

Table 3: Effect of $\mathrm{NaCl}$ Concentrations on Bacteriocin Production by KS1

\begin{tabular}{lllll}
\hline $\mathrm{NaCl}$ & \multicolumn{2}{c}{ Zone of inhibition in diameter (mm) } & D-3 & D-4 \\
Concentration & $\mathrm{D}-1$ & $\mathrm{D}-2$ & 2 & 2 \\
\hline Control & 10 & 4 & 2 & 2 \\
$0.5 \%$ & 6 & 6 & 2 & 2 \\
$1 \%$ & 6 & 6 & 2 & 2 \\
$2.5 \%$ & 6 & 20 & 2 & 2 \\
$5 \%$ & 6 & 4 & 2 & \\
\hline
\end{tabular}

Table 4: Effect of Organic Solvents on Bacteriocin Activity Produced by KS1

\begin{tabular}{lll}
\hline Organic solvents & Zone of inhibition in diameter $(\mathrm{mm})$ & $\mathrm{AU} / \mathrm{mL}$ \\
\hline Formaldehyde & 10 & 80 \\
Chloroform & 10 & 160 \\
Methanol & 6 & 160 \\
Control & 10 & 160 \\
\hline
\end{tabular}

Table 5: Effect of Surfactant on Bacteriocin Activity

\begin{tabular}{lll}
\hline Surfactants & Zone of inhibition in diameter $(\mathrm{mm})$ & AU/mL \\
\hline Tween 20 & 10 & 160 \\
EDTA & 26 & 160 \\
SDS & 10 & 160 \\
\hline
\end{tabular}


Table 6: Biochemical Tests for the Isolated Bacterial Strains

\begin{tabular}{|c|c|c|c|c|}
\hline BIOCHEMICAL TEST & KS1 & KS2 & KS3 & KS4 \\
\hline Morphology & Rod & Rod & Rod & Rod \\
\hline Gram stain & $+\mathrm{ve}$ & $+\mathrm{ve}$ & + ve & $+\mathrm{ve}$ \\
\hline Indole & - & - & - & _ \\
\hline Vogues & - & - & _ & _ \\
\hline Citrate & + & + & + & + \\
\hline Catalase & - & - & - & - \\
\hline Urease & - & - & - & - \\
\hline TSI & + & + & + & + \\
\hline Milk agar & + & + & + & + \\
\hline Tributyrin agar & + & + & + & + \\
\hline
\end{tabular}

Table 7: Antibiotic Sensitivity Test of KS1Strain

\begin{tabular}{llll}
\hline Antibiotic disc & Diameter $(\mathrm{mm})$ & \\
\hline 1 & Gentamicin & 16.0 & Inference \\
2 & Co-trimoxazole & 30.0 & Sensitive \\
3 & Azithromycin & 22.0 & Sensitive \\
4 & Tetracycline & 22.0 & Sensitive \\
5 & Amoxicillin & 6.0 & Sensitive \\
Resistant & Re \\
\hline
\end{tabular}

\section{References}

[1] De Vrese M. and Schrezenmeir J. (2008) Probiotics, Prebiotics, Synbiotics. Adv Biochem Eng Biotechnology 111,1-66 http://dx.doi.org/10.1007/10_2008_097.

[2] Brooks and Kalmokoff.(2012) . Prebiotics and Probiotics: Methodology, Efficacy, and Potential Health Considerations. J. of AOA $C$ International 95( 1)

[3] Vouloumanou.E.K., Makris G.C., Karageorgopoulos D.E., Falagas M.E.(2009) Probiotics for the prevention of respiratory tract infections: a systemic review.Int.J.Antimicrob Agents.34(3):197.e 1-10

[4] Hungin A.P., Mulligan.C, Pot.B., Whorwell P., Agreus.L., Fracasso P., Lionis C., Mendive.J., Philippart de foy J.M., Rubin G, Winchester C., de Wit.N.(2013) Systemic review: Probiotics in the management of lower gastrointestinal symptoms in clinical practice - an evidence based international guide.Aliment Pharmacol Ther.38(8),864-886. http://dx.doi.org/10.1111/apt.12460.

[5] Allen.S.J., Martinez.E.G., Gregario.G.V., Dans.L.F .(2010) Probiotics for curing acute infectious diarrhea.Cochrane Database Syst Rev.(11): CD003048.

[6] Heng NC, Burtenshaw GA, Jack RW, Tagg JR (2007) Ubericin A, a class IIa bacteriocin produced by Streptococcus uberis. Appl Environ Microbiol. 73:7763-7766 http://dx.doi.org/10.1128/AEM.01818-07.

[7] Cotter PD, Ross RP, Hill C. (2013). Bacteriocins - a viable alternative to antibiotics? Nat Rev Micro.11 (2):95-105. http://dx.doi.org/10.1038/nrmicro2937.

[8] Sahoo.T.K. Jena.P.K., Patel.A.K. and Seshadri.S (2014) Bacteriocins and their applications for the treatment of bacterial diseases in aquaculture: a review.Aquaculture Research.1-15

[9] Sahl, H.G., Bierbaum, G. (1998) Lantibiotics: Biosynthesis and biological activities of uniquely modifies peptides from Gram positive bacteria. Anu, Rev. Microbiol. 52, 41-79. http://dx.doi.org/10.1146/annurev.micro.52.1.41.

[10] Singh.M and Sareen.D (2014) Novel LanT associated lantibiotic clusters identified by genome database mining.

[11] Elizete de F.Reque, Ashok Pondey, sebastiao G. Franco, Carlos Soccol R. (2000) Isolation, identification and physiological study of Lactobacillus fermentum LPB for use as Probiotic in chickens. Brazilian journal of Microbiology; 31: 303-307.

[12] Bhunia, A.K., Johnson, M.C. and Ray, B. (1988) Purification characterization and antimicrobial spectrum of bacteriocin production by Pediococcus acidilactii. J. Appl. Bacteiol. 65, 261-268. http://dx.doi.org/10.1111/j.1365-2672.1988.tb01893.x.

[13] Rasool, S.A., Ahmed, S. and Iqbal, A. (1996) Streptococcins of indigenous haemolytic sterptococcin. Natural product letters. $8(01)$ 67-74. http://dx.doi.org/10.1080/10575639608043241.

[14] Muriana P.M. and Klaenhammer T.R. (1991) Purification and partial characterization of lactacin $\mathrm{F}$, a bacteriocin produced by Lactobacillus acidophilus 11088, Appl Environ Microbiol. 57(1): 114121.

[15] Hardy, R.G. (1982) Bacteriocins.In: Experiments in Microbial Scientific Publications. Ecology (burns, R.G. and Slater, J. H. Eds) Blackwell Edinburgh, 368-378.
[16] Pucci, M.J., Vedamuthu, E.R., Runka, B.s Vandenburgh, P.A. (1988) Inhibition of Listeria monocytogens by using bacteriocins PA-1 produced by pediococcusacidilactici PAC 1.0. Appl. Environ. Microbial. 54 (10), 2349-2353.

[17] Bhunia, A.K., Johnson, M.C. and Ray, B. (1991) Mode of action of PediocinAcH from Pediococcusacidilactici $H$ on sensitive bacterial strain. J. Appl. Bacteiol. 65, 261-268. http://dx.doi.org/10.1111/j.1365-2672.1988.tb01893.x.

[18] Vijayabaskar, P. and Somasundaram, S.T. (2008) Isolation of Bacteriocin Producing Lactic Acid Bacteria from Fish Gut and Probiotic Activity Against Fresh Water Fish Pathogen Aeromonas Hydrophila. Biotechnology 7 (1), 124-128. http://dx.doi.org/10.3923/biotech.2008.124.128.

[19] Veera Jothi, V., Anandapandian, K.T.K. and Shankar, T. (2012) Bacteriocin production by probiotic bacteria from curd and its field application. Archives of Applied Science Research 4 (1), 33-347.

[20] Sumathi, V., Reetha, D. (2009) Isolation and Screening of bacteriocin producing lactic acid bacteria from milk and milk products. Journal of Ecobiotechnology 1/1, 021-023.

[21] Natthida Chanprasert and Piyawan Gasaluck (2011) Bacteriocin production and its crude characterization of lactic acid bacteria isolated from pickled Garcinia schomburgkiana Pierre. As. J. Food Ag-Ind. 4(01), 54-64.

[22] Aguilar-Uscanga B. R., Solís-Pacheco J. R., Plascencia L., AguilarUscanga M. G., García H. S. and Lacroix M. (2013) AguilarUscanga et al., 2 (6) 2462-2468.

[23] Musikasang, H. Sohsomboon, N. Tani, A. Maneerat, S. (2012) Bacteriocin-producing lactic acid bacteria as a probiotic potential from Thai indigenous chickens. Czech J. Anim. Sci., 57, (3), 137-149.

[24] Mahsa Siamansouri, Sepideh Mozaffari and Fatemeh (Elham) Alikhani (2013) Bacteriocins and lactic acid bacteria. Journal of Biology and today's world 2(5), 227-234.

[25] Barbour A, Philip K (2014) Variable Characteristics of BacteriocinProducing Streptococcus salivarius Strains Isolated from Malaysian Subjects. PLoS ONE 9(6): http://dx.doi.org/10.1371/journal.pone.0100541. 